Jurnal Kesmas Asclepius

Volume 1, Nomor 1, Juni 2019

e-ISSN : 2684-8287

p-ISSN : 2656-8926

DOI: https://doi.org/10.31539/jka.v1i1.623

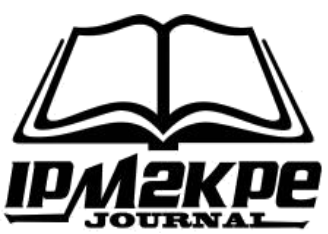

\title{
HUBUNGAN TINGKAT PENGETAHUAN IBU DAN USIA TERHADAP PENGGUNAAN ALAT KONTRASEPSI SUNTIK
}

\author{
Lia Hartini ${ }^{1}$, Omi Harera Prabusari ${ }^{2}$ \\ Dinas Pengendalian Penduduk dan Keluarga Berencana ${ }^{1,2}$ \\ liahartini65@gmail.com
}

\begin{abstract}
ABSTRAK
Penelitian ini bertujuan untuk mengetahui faktor-faktor yang berhubungan dengan penggunaan alat kontrasepsi suntik pada ibu yang berkunjung di Puskesmas Swasti Saba Kota Lubuklinggau Tahun 2019. Metode penelitian ini menggunakan deskriptif analitik dengan pendekatan cross sectional. Hasil ini didapatkan responden dengan pengetahuan baik $(43,3 \%)$, pengetahuan kurang $(56,8 \%)$, usia muda $(64,9 \%)$, usia tua $(35,1 \%)$, penggunaan alat kontrasepsi suntik $(51,4 \%)$ dan penggunaan alat kontrasepsi tidak suntik $(48,6 \%)$. Hasil uji statistik chi square diperoleh nilai $\rho>\alpha(0,05)$ untuk pengetahuan nilai $\mathrm{p}=0,129$ dan usia dengan nilai $\mathrm{p}=0,418$. Simpulan, tidak ada hubungan yang bermakna antara pengetahuan dan usia dengan penggunaan alat kontrasepsi suntik.
\end{abstract}

Kata Kunci : Kontrasepsi Suntik, Pengetahuan, Usia

\section{ABSTRACT}

This study aims to determine the factors associated with the use of injection contraceptives in mothers visiting the Swasti Saba Public Health Center in Lubuklinggau City in 2019. This research method uses descriptive analytic with a cross sectional approach. These results obtained respondents with good knowledge (43.3\%), lack of knowledge (56.8\%), young age (64.9\%), old age (35.1\%), use of injectable contraceptives (51.4\%) and the use of non-injectable contraceptives (48.6\%). Chi square statistical test results obtained value $\rho>\alpha(0.05)$ for knowledge of $p=0.129$ and age with a value of $p=0.418$. In conclusion, there is no significant relationship between knowledge and age with injection contraceptive use.

Keywords: Injection Contraception, Knowledge, Age

\section{PENDAHULUAN}

Berdasarkan estimasi yang diterbitkan oleh Biro Sensus Amerika Serikat, penduduk dunia mencapai 6,5 milyar jiwa. Dari sekitar 6,5 milyar penduduk dunia, 4 milyar diantaranya tinggal di Asia. Berikut adalah peringkat negara-negara di dunia berdasarkan jumlah penduduk (2005): Republik Rakyat Cina 1,306 jiwa, Amerika Serikat 298 juta jiwa, Indonesia 241 juta jiwa, Brasil 186 jita jiwa, Bangladesh 1.444 juta jiwa, Rusia 143 juta jiwa, Nigeria 128 juta jiwa, jepang 121 juta jiwa (Biro Sensus Amerika Serikat, 2006). 
Salah satu kebijakan dalam menanggulangi masalah kependudukan di Indonesia adalah dengan memberikan memberikan pengetahuan tentang kependudukan dan KB. Manfaat KB adalah untuk menekan jumlah kepadatan penduduk, program KB menentukan kualitas keluarga, karena program ini dapat menyelamatkan kehidupan perempuan serta meningkatkan status kesehatan ibu terutama dalam mencegah kehamilan tak diinginkan, menjarangkan jarak kelahiran mengurangi resiko kematian bayi, selain memberi keuntungan ekonomi pada pasangan suami istri, keluarga dan masyarakat, KB juga membantu remaja mengambil keputusan untuk memilih kehidupan yang lebih baik dengan merencanakan proses reproduksinya. Program KB bisa meningkatkan pria untuk ikut bertanggung jawab dalam kesehatan reproduksi mereka dan keluargaya, ini merupakan keuntungan seseorang mengikuti program $\mathrm{KB}$ (BKKBN, 2009).

Keluarga Berencana (KB) merupakan upaya peningkatan kepedulian dan peran serta masyarakat melalui pendewasaan usia perkawinan (PUP), pengaturan kelahiran, pembinaan ketahanan keluarga, peningkatan kesejahteraan keluarga kecil, bahagia dan sejahtera. Untuk mengatur jarak kelahiran salah satunya adalah dengan pemakaian alat kontrasepsi bagi PUS (Dyah \& Sujiyatini, 2009).

Banyak wanita harus menentukan pilihan kontrasepsi yang sulit. Tidak hanya karena terbatasnya jumlah metode yang tersedia, tetapi juga oleh ketidaktahuan mereka tentang persyaratan dan keamanan metode kontrasepsi tersebut. Karena metode-metode tersebut mungkin tidak dapat menerima sehubungan dengan kebijakan nasional KB, kesehatan individual, dan seksualitas wanita atau biaya untuk memperoleh kontrasepsi. Dalam suatu metode, wanita harus menimbang berbagai faktor termasuk status kesehatan mereka, efek samping potensial suatu metode, konsekuen terhadap kehamilan yang tidak diinginkan, besarnya keluarga yang diinginkan, kerjasama pasangan dan norma budaya mengenai kemampuan mempunyai anak.

Kontrasepsi suntik memiliki kelebihan dan kekurangan. Kontrasepsi suntik merupakan obat pencegah kehamilan yang cara pemakaiannya dengan menyuntikkan kepada wanita subur. Obat suntik KB berisi Depo Medorxi Progesterone Acetate (DMPA). Penyuntikkan dilakukan pada otot (intramuskuler) dibagian gleteus yang dalam atau pangkal lengan (deltoid). Kontrasepsi ini baik untuk wanita menyusui dan dipakai segera setelah melahirkan. Suntikan pertama diberikan dalam waktu empat minggu setelah melahirkan. Suntikan kedua diberikan tiap bulan berikutnya. Kontrasepsi suntik efektif untuk mencegah kehamilan jika pemakaiannya teratur. Alat kontrasepsi ini bisa digunakan bagi wanita berbagai golongan umur, baik yang telah beranak atau belum beranak. Selain itu alat kontrasepsi ini efektivitasnya tinggi, pemakaiannya sederhana juga aman dipakai selama masa menyusui, membantu mencegah kanker rahim, dan mencegah kehamilan diluar rahim. Faktor-faktor inilah yang mendorong pemakaian kontrasepsi suntik disukai oleh wanita usia subur (BKKBN, 2005).

Pemakaian kontrasepsi suntik juga harus memperhatikan efek samping. Pemilihan KB suntik perlu perhatian khusus, terutama bagi wanita usia diatas 35 tahun mengingat resiko yang timbul seperti serangan jantung, stroke dan masalah perubahan tekanan darah. Kelemahan dari kontrasepsi suntik adalah terganggunya pola haid diantaranya adalah amenorhoe, menoragia dan muncul bercak (spotting), pertambahan berat badan dan alergi (BKKBN, 2004). 
Setiap metode mempunyai kelebihan dan kekurangan. Namun demikian, meskipun telah mempertimbangkan untung rugi semua kontrasepsi yang tersedia, tetap saja terdapat kesulitan untuk mengontrol fertilitas secara aman, efektif dengan metode yang dapat diterima, baik secara perseorangan maupun budaya pada berbagai tingkat reproduksi. Tidaklah mengejutkan apabila banyak wanita merasa bahwa penggunaan kontrasepsi terkadang problematis dan mungkin terpaksa memilih metode yang tidak cocok dengan konsekuensi yang merugikan atau tidak menggunakan metode KB sama sekali.

Sesuai dengan teori Green (1980) dalam Notoatmodjo (2010) bahwa perilaku kesehatan termasuk didalamnya pemilihan alat kontrasepsi dipengaruhi oleh tiga faktor yaitu faktor predisposing (pengetahuan, sikap, pendidikan, ekonomi keluarga), faktorfaktor pendukung (ketersediaan alat kesehatan, sumber informasi) serta faktor pendorong (dukungan keluarga dan tokoh masyarakat).

Pengetahuan merupakan pemahaman secara internal berdasarkan pada fakta-fakta ilmiah, pengalaman atau kepercayaan tradisional. Pengalaman menunjukkan bahwa pengetahuan itu penting tetapi tidak cukup untuk mengubah suatu tindakan karena ada faktor lain yang mempengaruhi seperti persepsi, motifasi, keterampilan/keahlian dan lingkungan sosial.

Usia adalah hidup seseorang sejak dilahirkan sampai pada ulang tahun terakhirnya (Ali, 2002). Usia merupakan variabel yang digunakan sebagai ukuran mutlak atau indikator fisikologis seseorang menggunakan fasilitas dan pelayanan kesehatan. Dengan kata lain dimana usia yang semakin lama akan menambah pengalaman belajar yang merupakan konsekuensi dari pengalaman (Notoatmdjo, 2005).

Sasaran gerakan KB Nasional adalah Pasangan Usia Subur (PUS). Sementara pada Pendataan Keluarga Tahun 2015 tercatat jumlah pasangan usia subur (PUS) sebanyak 6.879 pasangan.

Di Indonesia kegiatan keluarga berencana sangat tinggi dalam penggunaan Non Metode Kontrasepsi Jangka panjang (NON MKJP). Bila dilihat dari cara pemakaian alat kontrasepsi dapat dikatakan bahwa 51,21\% akseptor KB memilih suntikan sebagai alat kontrasepsi, 40,02 \% memilih pil 4,93\% memilih Implant, 2,72 \% memilih IUD dan lainnya $1,11 \%(\mathrm{BKKBN}, 2005)$.

\section{METODE PENELITIAN}

Penelitian ini bersifat survey analitik dengan pendekatan cross sectional dimana variabel pengetahuan dan usia ibu serta variabel pemakaian kontrasepsi suntik dikumpulkan dalam waktu yang bersamaan. Populasi dalam penelitian ini adalah semua akseptor KB pada ibu yang berkunjung di Puskesmas Swasti Saba pada bulan Februari tahun 2019 sebanyak 185 Akseptor. Sampel diambil dari keseluruhan objek yang diteliti yaitu semua Akseptor KB yang berkunjung di Puskesmas Swasti Saba Kota Lubuklinggau. Pengambilan sampel yaitu dengan cara accidental sampling yaitu dengan mengambil kasus atau responden yang kebetulan ada atau tersedia pada saat peneliti melakukan penelitian dari tanggal 01 sampai dengan 28 Februari 2019.

Besar sampel pada penelitian ini adalah $20 \%$ dari jumlah populasi. Ketetapan $20 \%$ dipakai saat jumlah populasi kurang dari 1000 lebih dari $100>\mathrm{N}=\underline{20} \times 185=37$ Responden.100

Sedangkan kriteria sampel adalah bersedia menjadi responden (bisa membaca dan menulis) dan sebagai Akseptor KB yang berkunjung di Puskesmas Swasti saba Kota lubuklinggau. Tempat penelitian di lakukan di Puskesmas Swasti Saba Kota 
Lubuklinggau. Pengambilan data terhadap sampel penelitian dilakukan oleh peneliti dengan cara wawancara dan kuesioner dari sampel yang diteliti. Adapun sumber data adalah 1. Data primer yaitu pengumpulan data dilakukan dengan wawancara berstruktur yang menggunakan pedoman wawancara dan pengamatan. Responden pada peneliti adalah ibu yang menggunakan KB yang berkunjung di Puskesmas Swasti saba Kota Lubuklinggau Tahun 2019. 2. Data Sekunder adalah data yang diperoleh dari Dinas Pengendalian Penduduk dan Keluarga Berencana Kota Lubuklinggau.

Teknik Pengumpulan Data dikumpulkan dengan menggunakan kuesioner yang telah disiapkan dengan cara wawancara kepada responden, Peneliti melakukan sendiri wawancara secara sistematis dengan lembar kasus yang berisi tentang biodata responden lembar kuesioner tentang tingkat pengetahuan dan usia. Instrumen pengumpulan data yaitu dengan alat dan lembar kuesioner. Sedangkan teknik pengolahan data menggunakan coding, editing, entry, dan cleaning. Coding merupakan kegiatan merubah data berbentuk huruf menjadi data berbentuk angka atau bilangan. Kegunaannya adalah untuk mempermudah pada saat analisis data dan juga mempercepat pada saat entry data. Editing merupakan kegiatan untuk melakukan pemeriksaan isian kuisioner apakah jawaban sudah lengkap, jelas relevan dan konsisten. Entry adalah merupakan data-data yang sudah dicoding dan di editing selanjutnya akan dimasukkan di tabel. Dan terakhir adalah Cleaning merupakan kegiatan pengecekkan kembali data yang sudah di entry apakah ada kesalahan atau tidak.

Adapun teknik analis data yang digunakan adalah Analisis Univariat dan Analisis Bivariat. Analisis Univariat dilakukan untuk menjelaskan atau mendeskripsikan karakteristik setiap variabel penelitian yaitu faktor-faktor yang berhubungan dengan penggunaan alat kontrasepsi di Puskesmas Swasti Saba Kota Lubuklinggau tahun 2019. Sedangkan analisis bivariat dilakukan terhadap dua variabel yang diduga berhubungan atau korelasi. Analisis ini digunakan untuk mengetahui hubungan antara variabel independen (Pengetahuan dan usia) dan variabel dependen (Penggunaan kontrasepsi suntik) digunakan uji statistik chi square dengan derajat kemaknaan $\alpha=0,05$ yang diperoleh dari analisis chi square yaitu : nilai $p$ kemudian dibandingkan dengan $\alpha=0,05$ , apabila nilai $p \leq \alpha(0,05)$ maka ada hubungan antara kedua variabel tersebut, dan apabila nilai $p$ value $\geq \alpha(0,05)$ maka tidak ada hubungan antara kedua variabel tersebut.

\section{HASIL PENELITIAN}

Tabel.1

Frekuensi Responden

Berdasarkan Pengetahuan

\begin{tabular}{llcccc}
\hline & & Frequency & Percent & Valid Percent & Cumulative Percent \\
\hline Valid & Baik & 16 & 43.2 & 43.2 & 43.2 \\
& Kurang & 21 & 56.8 & 56.8 & 100.0 \\
& Total & 37 & 100 & 100 & \\
\hline
\end{tabular}

Berdasarkan tabel 1, dapat dilihat bahwa sebagian besar responden berpengetahuan kurang yaitu 21 orang ( 56,8\%), dan yang berpengetahuan baik sebanyak 16 orang $(43,2 \%)$. 
Tabel. 2

Frekuensi Responden

Berdasarkan Usia

\begin{tabular}{llcccc}
\hline & Frequency & Percent & Valid Percent & $\begin{array}{c}\text { Cumulative } \\
\text { Percent }\end{array}$ \\
\hline Valid & Muda & 24 & 64.9 & 64.9 & 64.9 \\
& Tua & 13 & 35.1 & 35.1 & 100.0 \\
& Total & 37 & 100.0 & 100.0 & \\
\hline
\end{tabular}

Berdasarkan tabel 2, memperlihatkan bahwa responden yang berusia muda sebanyak 24 responden $(64,9 \%)$, dan yang usia tua 13 responden $(35,1 \%)$.

Tabel. 3

Frekuensi Responden

berdasarkan Penggunaan Alat Kontrasepsi Suntik

\begin{tabular}{llcccc}
\hline & Frequency & Percent & Valid Percent & $\begin{array}{c}\text { Cumulative } \\
\text { Percent }\end{array}$ \\
\hline Valid & Ya & 19 & 51.4 & 51.4 & 51.4 \\
& Tidak & 18 & 48.6 & 48.6 & 100.0 \\
& Total & 37 & 100.0 & 100.0 & \\
\hline
\end{tabular}

Berdasarkan tabel. 3 dapat dilihat bahwa dari 37 responden sebanyak 19 responden $(51,4 \%)$ menggunakan kontrasepsi suntik, sedangkan yang tidak menggunakan kontrasepsi suntik 18 responden $(48,6 \%)$.

Tabel. 4

Hubungan Pengetahuan Responden dengan Penggunaan Alat Kontrasepsi Suntik

\begin{tabular}{lccccccc}
\hline \multirow{1}{*}{ Pengetahuan } & \multicolumn{4}{c}{ Suntik } & \multicolumn{2}{c}{ Total } & \multirow{2}{*}{ Probability } \\
& $\mathrm{N}$ & $\%$ & $\mathrm{~N}$ & $\%$ & $\mathrm{~N}$ & $\%$ & \\
\hline Baik & 11 & 68,8 & 10 & 31,3 & 16 & 100 & 0,129 \\
Kurang & 8 & 38,1 & 8 & 61,9 & 21 & 100 & \\
Jumlah & 19 & 51,4 & 18 & 48,6 & 37 & 100 & \\
\hline
\end{tabular}

Tabel. 4 memperlihatkan bahwa responden yang berpengetahuan baik menggunakan alat kontrasepsi suntik ada 11 orang $(68,8 \%)$ dan yang berpengetahuan kurang menggunakan alat kontrasepsi suntik ada 8 orang $(38,1 \%)$. Sedangkan yang berpengetahuan baik tidak menggunakan alat kontrasepsi suntik ada 5 orang ( $31,3 \%)$ dan yang berpengetahuan kurang tidak menggunakan alat kontrasepsi suntik ada 13 orang $(61,9 \%)$. Hasil Uji Statistik diperoleh $\rho=0,129>0,05$ dengan demikian tidak ada hubungan yang bermakna antara pengetahuan dengan penggunaan alat kontrasepsi suntik. 
Tabel. 5

Hubungan Usia Responden

dengan Penggunaan Alat Kontrasepsi Suntik

\begin{tabular}{cccccccc}
\hline \multirow{2}{*}{ Usia } & \multicolumn{2}{c}{ Ya } & \multicolumn{2}{c}{ Tuntik } & \multicolumn{2}{c}{ Total } & \multirow{2}{*}{ Probability } \\
& $\mathrm{N}$ & $\%$ & $\mathrm{~N}$ & $\%$ & $\mathrm{~N}$ & $\%$ & \\
\hline Muda & 14 & 58,3 & 10 & 41,7 & 24 & 100 & 0,418 \\
Tua & 15 & 38,5 & 8 & 61,5 & 13 & 100 & \\
Jumlah & 19 & 51,4 & 18 & 48,6 & 37 & 100 & \\
\hline
\end{tabular}

Tabel. 5 memperlihatkan bahwa responden yang berusia muda menggunakan alat kontrasepsi suntik ada 14 orang $(58,3 \%)$ dan yang berusia tua menggunakan alat kontrasepsi suntik ada 5 orang $(38,5 \%)$. Sedangkan berusia muda tidak menggunakan alat kontrasepsi suntik ada 10 orang $(41,7 \%)$ dan yang berusia tua tidak menggunakan alat kontrasepsi suntik ada 8 orang $(61,5 \%)$. Hasil uji statistik diperoleh $\rho=0,418>$ 0,05 dengan demikian tidak ada hubungan yang bermakna antara usia dengan penggunaan alat kontrasepsi suntik.

\section{PEMBAHASAN}

Dari hasil penelitian ini didapatkan dari 37 responden yang menjadi sampel penelitian, terdapat 19 responden $(51,4 \%)$ menggunakan alat kontrasepsi suntik dan 18 responden $(48,6 \%)$ tidak menggunakan alat kontrasepsi suntik. Berdasarkan data tersebut di atas memang tidak banyak terdapat perbedaan antara jumlah penggunaan alat kontrasepsi suntik dengan yang tidak menggunakan alat kontrasepsi, hal ini kemungkinan disebabkan oleh berbagai faktor diantaranya tingkat pengetahuan ibu yang tinggi, informasi yang terbuka dan adanya penyuluhan-penyuluhan.

Menurut Dyah \& Sujiatini (2009) kontrasepsi suntik dinilai praktis, mudah didapat, serta relatif murah, sangat efektif, efek samping sangat kecil, tidak mengandung estrogen sehingga tidak berdampak serius terhadap penyakit jantung dan gangguan pembekuan darah, tidak memiliki pengaruh terhadap ASI, klien tidak perlu menyimpan obat suntik dapat digunakan oleh perempuan $>35$ Tahun sampai perimenopause.

Sedangkan hasil penelitian mengenai pengetahuan ini didapatkan bahwa dari 37 responden yang menjadi sampel, terdapat 16 responden $(43,2 \%)$ dengan pengetahuan baik, sementara pengetahuan kurang ada 21 orang (56\%). Hal ini dapat disebabkan karena pendidikan responden kurang, dan ada yang berpendidikan tinggi namun kurang informasi tentang penggunaan alat kontrasepsi. Pengetahuan dalam hal ini adalah informasi yang diterima akseptor berkenaan program $\mathrm{KB}$, alat kontrasepsi dan bagaimana memperoleh pelayanannya. Pengetahuan yang digunakan disini adalah pengetahuan tentang KB yang berhubungan dengan alat kontrasepsi suntik.

Banyak perempuan yang mengalami kesulitan dalam menentukan pilihan jenis kontrasepsi. Hal ini tidak hanya karena terbatasnya metode yang tersedia, tetapi juga oleh ketidaktahuan mereka tentang persyaratan dan keamanan metode kontrasepsi tersebut. Berbagai faktor harus dipertimbangkan termasuk status kesehatan, efek samping, potensial, konsekuensi kegagalan/kehamilan yang tidak diinginkan, besar keluarga yang direncanakan, persetujuan pasangan bahkan norma budaya lingkungan integral yang tinggi dalam pelayanan (BKKBN, 2005). 
Seorang yang memiliki pengetahuan baik akan cenderung memilih alat kontrasepsi yang sesuai dan cocok digunakannya. Karena dengan pengetahuan yang baik seseorang akan lebih mudah menerima informasi terutama tentang alat kontrasepsi (Nursalam, 2009).

Pengetahuan merupakan pemahaman secara internal berdasarkan pada fakta-fakta ilmiah, pengalaman atau kepercayaan tradisional. Pengalaman menunjukkan bahwa pengetahuan itu penting tetapi tidak cukup untuk mengubah suatu tindakan karena ada faktor lain yang mempengaruhi seperti persepsi, motifasi, keterampilan/keahlian dan lingkungan sosial.

Pengetahuan didapat dengan menggunakan motifasi-motifasi yang benar dari informasi yang ada. Inovasi yang komplek membutuhkan cara-cara memperoleh pengetahuan yang lebih, jika jumlah pengetahuan cukup dan tidak dikembangkan guna memperoleh suatu perubahan (Inovasi) (Biran, 2004).

Berdasarkan pengamatan selama melaksanakan proses penelitian, pengetahuan ibu terhadap penggunaan alat kontrasepsi suntik masih kurang kemungkinan di sebabkab oleh ketidakmauan ibu terhadap kenyamanan penggunaan alat kontrasepsi tersebut seperti rasa nyeri, takut akan resiko dan edema.

Berdasarkan penelitian menurut usia didapat bahwa dari 37 responden yang menjadi sampel, terdapat 24 responden $(64,9 \%)$ dengan usia muda ( $<30$ tahun), sedangkan usia tua ( $\geq 30$ tahun) yaitu 13 responden $(35,1 \%)$. Usia mempengaruhi akseptor dalam penggunaan alat kontrasepsi. Dari faktor usi dapat ditentukan fase-fase: Menunda kehamilan: usia istri/ibu <20 tahun, menjarangkan kehamilan: 20-30 tahun, mengakhiri kesuburan: > 30 tahun (Hanafi, 2004).

Usia merupakan variabel yang digunakan sebagai ukuran mutlak atau indikator fisikologis seseorang menggunakan fasilitas dan pelayanan kesehatan. Dengan kata lain dimana usia yang semakin lama akan menambah pengalaman belajar yang merupakan konsekuensi dari pengalaman (Notoatmodjo, 2005).

Sesuai dengan teori Green (1980) dalam Notoatmodjo (2010) bahwa perilaku kesehatan termasuk didalamnya pemilihan alat kontrasepsi dipengaruhi oleh tiga faktor yaitu faktor predisposing (pengetahuan, sikap, pendidikan, ekonomi keluarga), faktorfaktor pendukung (ketersediaan alat kesehatan, sumber informasi) serta faktor pendorong (dukungan keluarga dan tokoh masyarakat).

Menurut hasil penelitian mengenai hubungan pengetahuan dengan penggunaan alat kontrasepsi suntik didapat bahwa dari 37 responden yang berpengetahuan baik menggunakan alat kontrasepsi suntik ada 11 orang $(68,8 \%)$ dan yang berpengetahuan kurang menggunakan alat kontrasepsi suntik ada 8 orang $(38,1 \%)$. Hasil uji statistik diperoleh $\rho=0,129>0,05$ dengan demikian tidak ada hubungan yang bermakna antara pengetahuan dengan alat kontrasepsi suntik.

Hal ini tidak sesuai dengan pendapat Nursalam (2009) yang mengatakan bahwa pada umumnya pengetahuan seseorang dipengaruhi oleh pendidikan yang pernah diterima, semakin tinggi tingkat pendidikan seseorang maka semakin baik pula tingkat pengetahuannya. Belum tentu orang yang berpendidikan tinggi itu pengetahuannya lebih tinggi. Semua itu tergantung keaktifan wanita pasangan usia subur dalam mencari dan menerima informasi tentang kontrasepsi suntik.

Hal ini sama dengan adanya penelitian yang dilakukan Indira (2009) yang menyebutkan bahwa tidak ada hubungan antara faktor tingkat pengetahuan dengan pemilihan kontrasepsi. Namun pada penelitian yang dilakukan Aida (2001) didapatkan 
hasil bahwa ada hubungan antara faktor tingkat pengetahuan dengan pemilihan kontrasepsi.

Dalam teori WHO, dijelaskan bahwa pengetahuan dipengaruhi oleh pengalaman seseorang, faktor-faktor luar orang tersebut (lingkungan), baik fisik maupun non fisik dan sosial budaya yang kemudian pengalaman tersebut diketahui, dipersepsikan, diyakini sehingga menimbulkan motivasi, niat untuk bertindak dan pada akhirnya terjadi perwujudan niat berupa perilaku.

Berdasarkan teori tersebut dapat disimpulkan bahwa penggunaan suntik tidak hanya dipengaruhi oleh pengetahuan tetapi juga dipengaruhi ketersediaan alat kontrasepsi, ketidak cocokan individu menggunakan alat kontrasepsi suntik, alergi, haid tidak teratur dan banyak faktor lain yang mempengaruhi pengetahuan seseorang. Ibuibu yang tingkat kemampuannya tinggi terhadap alat kontrasepsi suntik belum tentu akan meggunakan kontrasepsi suntik, khususnya ibu-ibu di Puskesmas Swasti Saba Kota Lubuklinggau karena banyak hal yang harus dipertimbangkan yaitu kenyamanan, keaktifan, resiko dan biaya sehingga hasil penelitian ini menghasilkan hubungan yang tidak signifikan.

Hubungan usia dengan penggunaan alat kontrasepsi suntik berdasarkan hasil penelitian ini didapatkan bahwa dari 37 responden yang berusia muda (<30 Tahun) menggunakan alat kontrasepsi suntik ada 14 orang $(58,3 \%)$ dan yang berusia tua $(\geq 30$ tahun) menggunakan alat kontrasepsi suntik ada 5 orang $(38,5 \%)$. Hasil uji statistik menunjukkan tidak ada hubungan yang bermakna antara usia ibu dengan penggunakan alat kontrasepsi.

Pemakaian kontrasepsi suntik harus memperhatikan efek samping. Pemilihan KB suntik perlu perhatian khusus, terutama bagi wanita usia di atas 35 tahun mengingat resiko yang timbul seperti serangan jantung, stroke dan masalah perubahan tekanan darah. Kelemahan dari kontrasepsi suntik adalah terganggunya pola haid diantaranya adalah amenorhoe, menoragia dan muncul bercak (spotting), pertambahan berat badan dan alergi (BKKBN, 2004).

Setiap metode mempunyai kelebihan dan kekurangan. Namun demikian, meskipun telah mempertimbangkan untung rugi semua kontrasepsi yang tersedia,tetap saja terdapat kesulitan untuk mengontrol fertilitas secara aman, efektif, dengan metode yang dapat diterima, baik secara perseorangan maupun budaya pada berbagai tingkat reproduksi. Tidaklah mengejutkan apabila banyak wanita merasa bahwa penggunaan kontasepsi terkadang problematis dan mungkin terpaksa memilih metode yang tidak cocok dengan konsekuensi yang merugikan atau tidak menggunakan metode KB sama sekali.

Dari hasil wawancara, alasan responden yang berusia muda tetapi tidak menggunakan alat kontrasepsi suntik adalah karena responden merasa tidak cocok dan mengalami ketidakteraturan dalam siklus haid. Dan ada sebagian responden yang mengatakan tidak tahu bahwa usia muda ( $<30$ tahun) dianjurkan menggunakan kontrasepsi suntik dan pil.

Dari segi kepercayaan masyarakat, seseorang yang lebih dewasa akan lebih percaya diri dari orang yang belum cukup kedewasaannya. Meski teori mengatakan semakin cukup usia, tingkat kematangan dan kekuatan seseorang akan lebih matang dalam berfikir dan bekerja. Berarti usia yang semakin matang akan memudahkan wanita pasangan usia subur dalam menerima pengetahuannya tentang kontrasepsi suntik dan sebaliknya jika usia kurang matang akan menghambat seseorang dalam menerima informasi tentang kontrasepsi suntik. 
Para akseptor yang mempunyai usia yang matang lebih bisa memilih dan menerima informasi yang didapatnya sehingga mereka selalu aktif mencari informasi melalui penyuluhan dari petgas KB (Penyuluh Keluarga Berencana) ataupun lewat media massa. Tetapi ada juga sebagian kecil dari usia matang pengetahuannya kurang mungkin disebabkan akseptor tersebut kurang aktif dalam mendapatkan informasi ataupun kurang bergaul dengan masyarakat lainnya sehingga menghambat akseptor tersebut dalam menerima informasi.

Selain itu mengapa usia tidak berhubungan dengan penggunaan alat kontrasepsi suntik kemungkinan karena pengambilan sampel terlalu sedikit sehingga penelitian ini menghasilkan hubungan yang tidak signifikan.

\section{SIMPULAN}

Tidak ada hubungan yang bermakna antara pengetahuan dengan penggunaan alat kontrasepsi suntik di Puskesmas Swasti Saba Kota Lubuklinggau, serta tidak ada hubungan yang bermakna antara usia dengan penggunaan alat kontrasepsi suntik di Pusksmas Swasti Saba Kota Lubuklinggau tahun 2019.

\section{SARAN}

Saran dari penelitian ini diharapkan dapat memberikan informasi, pengetahuan, sumbangan pikiran tentang pelaksanaan keluarga berencana dengan metode kontrasepsi suntik serta perlu melakukan uji validasi dan reliabilitas terhadap alat ukur yang berupa kuisioner dan penambahan jumlah sampel apabila akan melakukan penelitian dalam hal yang sama.

\section{DAFTAR PUSTAKA}

Aida, N. (2001). Faktor-Faktor yang Berhubungan dengan Pemilihan Alat Kontrasepsi MKET dan non MKET pada Akseptor KB di Kelurahan Pasir Putih dan Bunja Timur Kecamatan Muara Bunja Kabupaten Bungo Jambi. available from : http://eprints.lib.ui.ac.id/6786/

Ali, M. (2002). Pengetahuan, Sikap, dan Perilaku Ibu bekerja dan Ibu Tidak Bekerja tentang Imnuin. Universitas Sumatera Utara

Biran, B. (2004). Obstetri dan Genekologi Sosial. Jakarta: Yayasan Bina Pustaka sarwono Prawiro Hardjo

Biro Sensus Amerika Serikat. (2006). Jumlah Penduduk Dunia. Diambil dari http://www.datastatistik-dunia.com

BKKBN. (2004). Siapa Peduli terhadap Remaja. Peduli terhadap Remaja: www.bkkbn.go.id

BKKBN. (2005). Keluarga Berencana dan Kesehatan Reproduksi. Jakarta: BKKBN

BKKBN. (2009). Data CPR, Jumlah Penduduk, di akses di http://bkkbn.go.id

Dinas Pengendalian Penduduk Keluarga Berencana. (2018). Kota Lubuklinggau

Dyah, G., \& Sujiyatini. S. (2009). Panduan Lengkap Pelayanan KB Terkini. Jogjakarta

Hanafi, H. (2004). Keluarga Berencana dan Kontrasepsi. Jakarta: Pustaka Sinar Harapan, Manuaba

Indira, L. (2009). Faktor-Faktor yang Mempengaruhi Pemilihan Jenis Kontrasepsi yang Digunakan pada Keluarga Miskin. Universitas Diponegoro

Notoatmodjo, S. (2010). Metodologi Penelitian Kesehatan. Rineka Cipta: Jakarta

Notoatmodjo. (2005). Metodologi Penelitian Kesehatan. Rineka Cipta: Jakarta 
2019. Jurnal Kesmas Asclepius 1 (1) 65-74

Nursalam, N. (2009). Konsep dan Penerapan Metodologi Penelitian Ilmu Keperawatan. Jakarta: Salembada Medika 